СОЦІАЛЬНЕ/СУСПІЛЬНЕ ЗАЛУЧЕННЯ УНІВЕРСИТЕТУ: АНАЛІЗ МІЖНАРОДНИХ ДОКУМЕНТІВ

\title{
COMMUNITY ENGAGEMENT OF UNIVERSITY: ANALYSIS OF THE INTERNATIONAL DOCUMENTS
}

у статmі проаналізовано європейські стратегічні документи ("Rome Ministerial Communiqué. Annex II Principles and Guidelines to Strengthen the Social Dimension of Higher Education in the EHEA", "Renewed EU agenda for higher education") та аналітичні звіти міжнародних організацій. З'ясовано, що community engagement (соціальне/суспільне залучення) є процесом, за допомогою якого заклади вищої освіти взаємодіють із зовнішніми стейкхолдерами громади для здійснення спільних заходів. Установлено, що пріоритетами у сорері вищої освіти країн Європи, присвяченими питанню сочіального/суспільного залучення університетів, $\epsilon$ такі: «Побудова інклюзивних і пов'язаних систем вищої освіти» й «Внесок закладів вищої освіти в розвиток інновацій і підприємництва». У межах першого пріоритету залучення університетів до розвитку міст, регіонів, громад пов'язано з участю в розробленні стратегій розвитку, співпрацею з бізнесом, публічним і волонтерським секторами; підготовкою спільних освітніх програм, притягнення представників місцевоі громади до викладання та реалізації дослідницьких проєктів та іншим У межах другого пріоритету - через розроблення нових рішень для розв'язання економічних, соціальних та екологічних проблем співпраця з майбутніми роботодавцями, інвестування в інновації здійснюється за принципом "Smart Specialisation" (Розумна спеціалізація) ma інше. З'ясовано зміст і різницю між поняттями "civic university (суспільний/міський університеm) $i$ "civically engaged university" (суспільно залучений університет)». Визначено ключові сорери, що мають потенціал для зростання соціального/суспільного залучення європейських університетів. До таких сорер віднесено: реформування академічноі кар'єри, сприяння міждисциплінарності, зміцнення civic engagement. Визначено характеристики університетів до 2030 року: відкритість, трансформаційність, транснаціональність, стійкість, різноманітність, залучення, потужність, автономність і підзвітність. З'ясовано наявність зв'язку між поняттями «університетська автономія» та «соціальна відповідальність університетів»; «університетська соціальна відповідальність» $і$ «фрінансування»; «університетська соціальна відповідальність» і «підзвітність університетів».

Ключові слова: інвестиції в інновації, розумна спеціалізація, сталий розвиток, суспільний/міський університет, суспільно залучений університет, угоди суспільних міських університетів, університетська автономія, університетська соціальна відповідальність, фрінансування університетів.

European strategic documents («Rome Ministerial Communiqué. Annex II Principles and Guidelines to Strengthen the Social Dimension of Higher Education in the EHEA", "Renewed EU agenda for higher education') and analytical reports of the international organizations are analyzed. Community engagement as a process whereby higher education institutions engage with external community stakeholders to undertake joint activities is outlined. Priorities of European higher education for university community engagement are identified, which include: "Building inclusive and connected higher education systems" and "Ensuring higher education institutions contribute to innovation". Within the first priority, universities are engaged in the development of their cities, regions, communities through contributing to development strategies, cooperation with businesses, the public and voluntary sectors, development of joint educational programs, involvement of local community representatives in teaching and implementation of research projects, etc. Within the second priority universities are engaged through the development of new solutions to economic, social and environmental problems, cooperation with future employers, investment in innovation on the principle of "Smart Specialization" and etc. The essence and difference between the terms "civic university" and "civically engaged university" are clarified. The key areas that have the potential to increase the community engagement of European universities are identified, which include: reforming academic careers, promoting interdisciplinarity and strengthen civic engagement. The characteristics of universities until 2030 are defined. All of Europe's universities will be open, transformative, transnational, sustainable, diverse, engaged, strong, autonomous and accountable. The correlation between the concepts of university autonomy and university social responsibility, university social responsibility and university funding; university social responsibility and university accountability is examined.

Key words: innovation investment, smart specialisation, sustainable development, civic university, civically engaged university, civic university agreements, university autonomy, university social responsibility, university funding.
Постановка проблеми в загальному вигляді. У Комюніке "Rome Ministerial Communiqué. Annex II Principles and Guidelines to Strengthen the Social Dimension of Higher Education in the EHEA" [1] (Римське міністерське комюніке. Додаток 2 Принципи та рекомендації щодо зміцнення соціального виміру вищої освіти в Європейському просторі вищої освіти, 2020, м. Рим) акцентовано на суспільному залученні закладів вищої освіти. Підкреслено, що «Заклади вищої освіти повинні забезпечити, щоб участь громади у вищій освіті сприяла різноманітності, справедливості й інклюзії» [1, с. 8]. Водночас у комюніке community engagement (соціальне/суспільне залучення) розглядається як «процес, за допомогою якого заклади вищої освіти взаємодіють із зовніш- 
німи стейкхолдерами громади для здійснення спільних заходів, що може бути взаємовигідним. Community engagement (соціальне/суспільне залучення) має бути закладено в основі місії вищої освіти, яка повинна містити викладання, навчання, дослідження, обмін послугами й знаннями, студентами й персоналом і менеджментом закладів вищої освіти» [1, с. 8]. Таке залучення забезпечує «цілісну основу, на якій університети можуть задовольнити широкий спектр суспільних потреб, включаючи потреби вразливих, незахищених і не досить представлених груп, одночасно збагачуючи свої навчальні, дослідницькі й інші основні фрункції» [1, с. 8]. За таких умов постає необхідність розглянути сутність та особливості соціального/суспільного залучення університету.

Аналіз останніх досліджень і публікацій, на які спирається автор і в яких розглядають цю проблему й підходи іï розв'язання. Особливості community engagement (соціального/суспільного залучення) у вищій освіті проаналізовано Т. Farnell [2], питання civic role (суспільної ролі) університетів перебуває в центрі уваги експертів European University Association [3], глобальні перспективи university civic engagement (суспільного/соціального залучення) розглянуто H. Lorlene [4].

Виділення не вирішених раніше частин загальної проблеми. Незважаючи на зростаючу кількість публікацій, присвячених соціальній відповідальності університетів (О. Оржель, 2017 рік [5]; О. Грішнова, С. Бех, 2014 рік [6]), дискусійними є питання системного розгляду соціального/суспільного залучення у сорері вищої освіти в контексті загальноєвропейських тенденцій.

Мета статті - 3'ясувати сутність і значення community engagement (суспільного/соціального залучення) університетів.

Виклад основного матеріалу дослідження 3 повним обґрунтуванням здобутих наукових результатів.

Повідомлення Європейської Комісії "Renewed EU agenda for higher education" [7] (Щодо оновленого порядку денного вищої освіти, 2017 рік) акцентує на ширшому суспільному/соціальному залученні університетів. У документі визначено два пріоритети, присвячених такому аспекту, а саме: «Побудова інклюзивних і пов'язаних систем вищої освіти» й «Внесок закладів вищої освіти в розвиток інновацій і підприємництва».

У межах першого означеного пріоритету акцентовано на проявах суспільного/соціального залучення університетів і підкреслюється значення останніх у взаємодії з громадою: «заклади вищої освіти - це не вежі зі слонової кістки, а "сіvісminded learning communities" (навчальні спільноти суспільного призначення), пов'язані зі своїми громадами» [7, с. 6]. На підтвердження цього наведемо цитати [7, с. 6]:
- «Інклюзивність систем вищої потребує забезпечення належних умов для студентів із соціально незахищених верств, у тому числі їх фрінансової підтримки». Іншими словами, важливим стає фрінансове забезпечення соціального виміру у сорері вищої освіти;

- «Подолання бар'єрів між вищою освітою та суспільством може допомогти студентам розвинути свої соціальні й суспільні/громадянські компетенції». Тобто суспільне/соціальне залучення університетів пов'язано з розвитком соціальних і суспільних компетентностей у студентів;

- «Деякі заклади розвивають свій профріль як "civic universities" (суспільні/громадянські університети), інтегруючи місцеві, регіональні й суспільні проблеми в освітні програми, залучаючи представників місцевої громади до викладання та реалізації дослідницьких проєктів, забезпечуючи навчання дорослих, здійснюючи комунікацію та налагоджуючи зв'язки з місцевими громадами»;

- «Заклади вищої освіти повинні бути залучені до розвитку своїх міст і регіонів чи то через участь у стратегіях розвитку, співпрацю з бізнесом, публічним і волонтерським секторами, чи через підтримку широкої дискусії з питань/проблем суспільства».

у межах пріоритету «Внесок закладів вищої освіти в розвиток інновацій і підприємництва» акцентовано на ширшій ролі закладів вищої освіти в місцевому й регіональному розвитку, a саме [7, с. 7$]$ :

- «розроблення нових рішень для розв'язання економічних, соціальних та екологічних проблем;

- орокусування на докторських програмах, що спрямовані на прикладне застосування знань і взаємодію з майбутніми роботодавцями» [7, с. 7];

- «<...> інвестування в інновації здійснюється на основі принципу "Smart Specialisation" (Розумна спеціалізація) - зосередження регіональних інвестицій і зусиль на інноваціях у секторах із високим потенціалом зростання» [7, с. 7];

- «Заклади вищої освіти можуть зробити більше для налагодження зв'язків між науковцями, підприємцями й державними органами влади, узгодити свою освітню пропозицію до потреб, визначених стратегіями розумної спеціалізації, скористатися можливостями для інновацій у пріоритетних секторах і допомогти місцевому бізнесу й іншим організаціям зрозуміти й прийняти нові способи мислення. Здійснення цього має бути частиною ширших культурних змін, завдяки яким заклади вищої освіти стають "entrepreneurial actors" (суб'єктами підприємницької діяльності)».

Таким чином, розбудова інклюзивних i пов'язаних систем вищої освіти передбачає ширше суспільне/соціальне залучення університетів, а розвиток інновацій і підприємництва пов'язаний з активізацією університетів як суб'єктів підприємницької діяльності. 
UPP Foundation Civic University Commission, "Truly Civic: Strengthening the connection between universities and their places', 2019 рік [8].

У звіті зазначається, що університет може розглядатися як "civic university" (суспільний/міський університет) лише тоді, коли мета - і стратегія підтримки цієї мети - передбачає позитивний суспільний вплив. Університети, які цього не здійснюють, але залучені у виконання важливої суспільної діяльності, можуть розглядатися лише як "civically engaged university" (суспільно залучений університет)» [8, с. 34].

Іншими словами, civic university (суспільний/ міський університет) має узгодити свою стратегію із суспільною місією для виконання своєї діяльності, результатом якої $€$ значний позитивний вплив на суспільство.

Щодо фрінансування civic university, у звіті рекомендовано створити на національному рівні спеціальний фонд - "Civic University Fund”, що акумулює ресурси для реалізації університетом своєї стратегії. Розмір фонду має складати 500 млн фунтів стерлінгів, а університети на конкурсних засадах отримуватимуть фрінансування в сумі від 20 до 30 млн фунтів стерлінгів для реалізації довгострокових проєктів.

Фонд повинен управлятися спільно Department for Education [9] (Департаментом освіти) в Англії та Department for Business, Energy and Industrial Strategy, BEIS [10] (Департаментом бізнесу, енергетики й індустріальної стратегії), спираючись на спільні відомчі компетенції Minister of State for Universities, Science, Research and Innovation (Міністра з питань університетів, науки, досліджень та інновацій), що відповідає за ці департаменти.

У документі підкреслюється прямий зв'язок між університетською автономією та соціальною відповідальністю: «університети є автономними інституціями з благодійним статусом. Вони проголошують і захищають цю автономію. Це означає, що вони також повинні брати на себе відповідальність за прийняття рішень - включаючи те, скільки та як збалансувати суспільні й інших вимоги» [8, с. 12].

Одним із можливих інструментів для співпраці між університетами, місцевою громадою та органами влади в процесі стратегічного аналізу, визначення пріоритетів, розуміння потреб місцевої громади є формування та підписання усіма сторонами угод "Civic University Agreements" [11, с. 8].

Узгодження civic university agreements із національними ініціативами й нормативними вимогами $€$ «інструментом підзвітності закладів вищої освіти на регіональному й національному рівнях» [12]. Civic university agreements «можуть стати для закладів вищої освіти механізмом покращення доступу, результатів навчання студентів та обміну знаннями одночасно з отриманням взаємної вигоди для місцевих громад, бізнесу й економіки» [12, с. 5].
Таким чином, у звіті акцентовано на розумінні самого поняття "civic university" (суспільний/міський університет), його місії, відповідальності й фрінансуванні.

European University Association, "Universities without walls. A vision for 2030", 2021 рік [13].

У звіті фрокусується увага на зростанні суспільної ролі університетів: «Підтвердження суспільної/ громадянської ролі університетів буде дедалі важливішою частиною соціального/суспільного залучення університету» $[13$, с. 6$]$.

Визначено такі характеристики університетів без стін, як: відкритість, трансформаційність, транснаціональність, стійкість, різноманітність, залучення, потужність, автономність і підзвітність [13, с. 5-7]. На підтвердження цього зазначено, що «<...> університети відкриті й залучені до суспільства, зберігаючи свої основні цінності. Усі європейські університети будуть відповідальними, автономними й вільними, з різними інституційними профрілями, але їх об'єднуватиме спрямування їх місій із навчання та викладання, досліджень, інновацій і культури на служіння суспільству» [13, с. 5]. Водночас "Sustainable development" (Сталий розвиток) буде основною рамкою для здійснення/спрямування впливу через університетські місії, оскільки університети активно обмірковують, знаходять і просувають рішення в діалозі із суспільством» $[13$, с. 6].

Університети «<..> будуть підзвітними за належне коригування принципів й цінностей, а також політики й діяльності. Це вимагатиме балансу між фрінансуванням стратегічних пріоритетів досліджень, збереженням свободи окремих дослідників і визнанням відповідальності університетів за забезпечення суспільства широкою базою знань через дослідження» [13, с. 6].

У документі наведено три ключові сорери, що мають потенціал для зростання societal engagement і сприяння сталому розвитку університетів Європи. До таких сорер віднесено [13, с. 12]: реорормування академічної кар'єри; сприяння міждисциплінарності; зміцнення civic engagement.

Висновки. У стратегічних позиціях на європейському рівні акцентовано на соціальному/суспільному залученні університетів, що підтверджено відповідними документами. Одними 3 пріоритетів у сорері вищої освіти визнано зростання соціальної/суспільної ролі університетів та їх активізація як суб'єктів підприємницької діяльності. Закріплення суспільної місії університетів у стратегії їх розвитку є відбиттям їх соціального/суспільного призначення. З'ясовано наявність зв'язку між: університетською автономією та соціальною відповідальністю університетів; соціальною відповідальністю та фрінансуванням; соціальною відповідальністю та підзвітністю університетів. Одним із важливих інструментів забезпечення підзвітності 
університетів $€$ civic university agreements. Перспективи подальших досліджень вбачаємо в аналізі соціального/суспільного залучення університетів на інституційному рівні.

\section{БІБЛІОГРАФІЧНИЙ СПИСОК:}

1. EHEA. Rome Ministerial Communiqué Annex II "Principles and Guidelines to Strengthen the Social Dimension of Higher Education in the EHEA". 2020. URL: https://ehea.info/Upload/Rome_Ministerial_ Communique_Annex_II.pdf.

2. Farnell T. Community engagement in higher education: trends, practices and policies. NESET report. Luxembourg: Publications Office of the European Union, 2020. DOI: 10.2766/071482. URL: https://op.europa.eu/ en/publication-detail/-/publication/e22067d5-c253-11eab3a4-01aa75ed71a1/language-en.

3. European University Association. Universities without walls. A vision for 2030. 2021. URL: https://eua. eu/downloads/publications/universities\%20without\%20 walls\%20\%20a\%20vision\%20for\%202030.pdf.

4. Lorlene H. University Civic Engagement: A Global Perspective. Higher Education Exchange. 2014. URL: https://www.kettering.org/sites/default/files/productdownloads/HEX-2014-final 0.pdf.

5. Оржель О. Університетська соціальна відповідальність у контексті університетського лідерства : навчальний посібник. Київ : ДП «НВЦ «Пріоритети», 2017. 40 c. URL: https://ihed.org.ua/wp-content/ uploads/2018/09/Sots_vidpovidalnist_v_Univ liderstve_O.Orzel_2017-40p.pdf.

6. Грішнова О., Бех С. Соціальна відповідальність університетів України: порівняльний аналіз та основні напрями розвитку. URL: http://bulletin-econom.univ. kiev.ua/wp-content/uploads/2015/11/158_11-18.pdf.
7. European Commission. Renewed EU agenda for higher education. Communication from the Commission to the European Parliament, the Council, the European Economic and Social Committee and the Committee of the Regions. 2017. URL: https://eur-lex.europa.eu/legal-content/EN/TXT/?uri= CELEX\%3A52017DC0247.

8. UPPFoundation Civic University Commission. Truly Civic: Strengthening the connection between universities and their places. 2019. URL: https://upp-foundation.org/ wp-content/uploads/2019/02/Civic-University-Commission-Final-Report.pdf.

9. Department for Education. URL: https://www.gov. uk/government/organisations/department-for-education.

10. UK Department for Business, Energy and Industrial Strategy. URL: https://www.gov.uk/government/ organisations/department-for-business-energy-and-industrial-strategy.

11. UPP Foundation Civic University Commission. A Guide to preparing Civic University Agreements. 2019. P. 8. URL: https://upp-foundation.org/wp-content/ uploads/2019/07/2202-UPP-Foundation-A-Guide-topreparing-Civic-University-Agreements-Booklet-A4digital.pdf.

12. Office for Students. Civic university agreements: exploring synergies with Office for Students access and participation regulation and funding. 2019. P. 5. URL: https://upp-foundation.org/wp-content/uploads/2019/07/ CUC-conference-Access-and-Participation-andCivic-University-Agreements-.pdf.

13. European University Association. Universities without walls. Avision for 2030. 2021. URL: https://eua.eu/ downloads/publications/universities $\% 20$ without $\%$ 20walls\%20\%20a\%20vision\%20for\%202030.pdf. 